\title{
Spectrum of histologic variants of papillary thyroid carcinoma over a period of 5 years- single institutional study
}

\author{
Uppala P. ${ }^{1}$, I.V. Renuka ${ }^{2}$, M. Atchyuta ${ }^{3}$, Sheik N. ${ }^{4}$, B. Garima ${ }^{5}$, K. Sireesha ${ }^{6}$ \\ ${ }^{1}$ Dr. Pravallika Uppala, 2 nd year Postgraduate, ${ }^{2}$ Dr. I.V. Renuka, Professor \& Head of Department, ${ }^{3}$ Dr. M. Atchyuta, Associate \\ Professor, ${ }^{4}$ Dr. Naseerudhin Sheik, $2^{\text {nd }}$ year post graduate, ${ }^{5}$ Dr. B. Garima, $3^{\text {rd }}$ year post graduate, ${ }^{6}$ Dr. K. Sireesha, $2^{\text {nd }}$ year \\ postgraduate; all authors are affiliated with Department of Pathology, NRI Institute of Medical Sciences, Chinakakani, Guntur, \\ Andhra Pradesh, India
}

Corresponding Author: Dr. M. Atchyuta, Associate Professor Department of Pathology, NRI Institute of Medical Sciences, Chinakakani, Guntur, Andhra Pradesh, India, NRI Institute of Medical Sciences. Email- atchyuta28@gmail.com

\begin{abstract}
Background: Thyroid carcinoma is the most common malignancy of endocrine system. They arise from two cell types present in the thyroid gland. The endodermally derived follicular cells give rise to papillary, follicular and probably anaplastic carcinomas. The neuroendocrine-derived calcitonin-producing $\mathrm{C}$ cells give rise to medullary carcinomas. Aims and Objectives: To study the different histological variants of papillary thyroid carcinoma (PTC) in thyroidectomy specimens, their frequency, age incidence, sex distribution and presence of metastasis in the regional lymph nodes. Materials and Methods: It was a retrospective study done in the department of Pathology over a period of 5 years from June 2014 - May 2019. Results: A total of 98 cases of papillary thyroid carcinomas were studied out of which 71 cases were of Classic variant, 19 cases of Follicular variant, 2 cases of Papillary Microcarcinoma variant, 1 case each of Cribriform Morular variant, Warthin like variant, Tall cell variant, Columnar cell variant, Oncocytic variant and Non invasive follicular thyroid neoplasm with papillary-like nuclear features (NIFTP). Conclusion: Classic variant of papillary carcinoma thyroid is the most common variant with the highest number of cases followed by follicular and other variants.
\end{abstract}

Keywords: Papillary thyroid carcinoma, Follicular variant, Tall cell, Columnar cell, Cribriform morular, Metastasis.

\section{Introduction}

Thyroid cancer is the most common endocrine malignancy with higher mortality rates compared to all other endocrine malignancies [1]. The recent data from National Cancer Registry Program show that thyroid cancer constitutes $3.96 \%$ of total cancers [2]. Papillary thyroid carcinoma (PTC) being the most common represents $80 \%-85 \%$ of thyroid cancers [3]. There has been a dramatic global increase in the reported incidence of thyroid cancer since the introduction of new, high-resolution imaging techniques (e.g. thyroid ultrasonography) into clinical practice. Almost all patients have clinically evident disease in the neck when they are first seen. In one large series, disease was localized to the thyroid gland in $67 \%$ of cases, thyroid and lymph nodes in $13 \%$, and lymph nodes alone in $20 \%$ [4].

The incidence rate in women is about 3 times the rate in men, but this disparity decreases with increasing patient age [4]. PTC usually presents as an asymptomatic (painless)

Manuscript received: $4^{\text {th }}$ November 2019

Reviewed: $14^{\text {th }}$ November 2019

Author Corrected: $20^{\text {th }}$ November 2019

Accepted for Publication: $25^{\text {th }}$ November 2019 thyroid mass with or without enlargement of regional (cervical) lymph nodes. Hoarseness and dysphagia occur in approximately $20 \%$ of cases, signaling recurrent laryngeal nerve involvement with vocal cord paralysis or tracheal compression. Nodal metastases in the lateral neck are reported in $27 \%$ of patients at presentation, most often originating from tumors in the ipsilateral thyroid lobe. Thyroid function testing has limited utility in the diagnosis of PTC because most patients have normal thyroid function [4].

Several variants of papillary thyroid carcinoma have been described based on the size (papillary microcarcinoma); nature of the tumor boundaries (encapsulated); architecture (follicular, macrofollicular, cribriform-morular, solid, micropapillary); cellular characteristics (tall cell, columnar, oncocytic, clear cell, hobnail) and other additional tumor components (papillary carcinoma with focal insular component, papillary carcinoma with spindle and giant cell carcinoma, papillary carcinoma with squamous cell carcinoma, papillary carcinoma with mucoepidermoid carcinoma); stromal features (papillary carcinoma with

Pathology Update: Tropical Journal of Pathology \& Microbiology Available online at: www.medresearch.in 934 | P a g e 
fasciitis like stroma); or a combination of the above mentioned characteristics (diffuse sclerosing, diffuse follicular) [5-8].

Microscopically almost all the variants of papillary thyroid carcinomas are characterized by neoplastic papillae that contain a central core of fibro vascular tissue lined by one or occasionally several layers of cells with crowded oval nuclei. Cytologically, the nuclei show characteristic crowding, overlapping, clearing, grooves and intra nuclear pink cytoplasmic inclusions.

Most of these variants do not pose any diagnostic problems where as some of these variants are a challenge to the pathologist and some are of clinical significance.

In the present study, analysis of the slides reported as papillary carcinoma was done, with special reference to its various histopathological variants, age and gender incidence.

\section{Materials and Methods}

Duration and type of study: The duration of the study is 5 years from June 2014 to May 2019 and it was a partly retrospective (4-1/2 years) and partly prospective (1/2 years) study done in the department of Pathology, NRI Medical College, Chinakakani.

Sampling methods: The sampling method employed in the study was a simple random sampling method.
Inclusion criteria: All the histopathologically proven cases of papillary thyroid carcinoma on hemithyroidectomy and total thyroidectomy specimens were included in the study.

Exclusion criteria: Needle core biopsies and benign lesions of thyroid were excluded.

Data collection procedure: Data collected in the present study included age, sex, histologic variants of papillary thyroid carcinoma and the presence of metastasis to cervical lymphnodes if present in these cases.

The data was collected from the clinico pathological files and histopathology slides were reviewed for further information.

Data analysis: All the specimens received were fixed in $10 \%$ formalin and then subjected to macroscopic examination. Representative samples were taken, processed and stained with routine $\mathrm{H} \& \mathrm{E}$ stains.

After collecting the data, the slides were reviewed and were classified according to WHO classification of tumors of Endocrine Organs, 2016.

All these cases were tabulated in Microsoft excel sheet and the data collected was statistically graded by using mean and percentages.

Ethical consideration \& permission: Institutional ethical clearance was obtained.

\section{Results}

A total of 98 cases of papillary thyroid carcinoma were studied and diagnosed various histological variants which are listed in Table-1.

Table-1: Histopathologic variants of papillary thyroid carcinoma

\begin{tabular}{|l|c|c|}
\hline Histological variants & No. of cases & \% of cases \\
\hline Classic variant & 71 & $72.4 \%$ \\
\hline Fol Follicular variant & 19 & $19.3 \%$ \\
\hline Papillary Microcarcinoma variant & 02 & $2.04 \%$ \\
\hline Warthin like variant & 01 & $1.02 \%$ \\
\hline Cribriform Morular variant & 01 & $1.02 \%$ \\
\hline NIFTP & 01 & $1.02 \%$ \\
\hline Oncocytic variant & 01 & $1.02 \%$ \\
\hline Tall cell variant & 01 & $1.02 \%$ \\
\hline Columnar cell variant & 01 & $1.02 \%$ \\
\hline
\end{tabular}

Among these 98 cases, the commonest age group was 31 to 40 years and is shown in Table-2. 
Table-2: Age distribution.

\begin{tabular}{|c|c|c|c|c|c|c|c|c|c|}
\hline \&o & 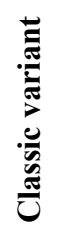 & 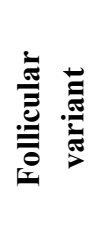 & 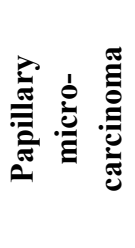 & 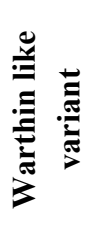 & 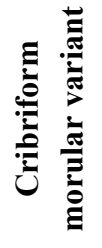 & 它 & 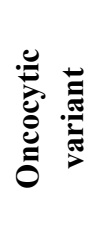 & 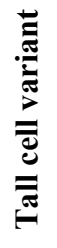 & 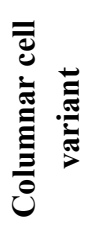 \\
\hline$<20$ & 03 & -- & -- & -- & -- & -- & -- & -- & -- \\
\hline $21-30$ & 15 & 03 & 02 & -- & -- & -- & -- & -- & -- \\
\hline $31-40$ & 23 & 06 & -- & -- & -- & 01 & 01 & -- & 01 \\
\hline $41-50$ & 13 & 03 & -- & -- & -- & -- & -- & 01 & -- \\
\hline $51-60$ & 07 & 04 & -- & 01 & -- & -- & -- & -- & -- \\
\hline $61-70$ & 06 & 03 & -- & -- & 01 & -- & -- & -- & -- \\
\hline $71-80$ & 04 & -- & -- & -- & -- & -- & -- & -- & -- \\
\hline$>80$ & -- & -- & -- & -- & -- & -- & -- & -- & -- \\
\hline Total & 71 & 19 & 02 & 01 & 01 & 01 & 01 & 01 & 01 \\
\hline
\end{tabular}

Classical type of papillary carcinoma was the predominant type in these age groups, followed by follicular variant. There were 76 female and 22 male patients with a male-to-female ratio of 1:3.4 and is tabulated in Table-3.

Table-3: Sex distribution among various papillary thyroid carcinomas.

\begin{tabular}{|l|c|c|c|}
\hline Type of the papillary variant & Females & Males & Ratio \\
\hline Classic variant & $55(77.5 \%)$ & $16(22.5 \%)$ & $3.5: 1$ \\
\hline Follicular variant & $14(73.6 \%)$ & $05(26.4 \%)$ & $3: 1$ \\
\hline Papillary microcarcinoma variant & $02(100 \%)$ & -- & Females only \\
\hline Warthin like variant & $01(100 \%)$ & -- & Females only \\
\hline Cribriform morular variant & $01(100 \%)$ & -- & Females only \\
\hline NIFTP & -- & $01(100 \%)$ & Males only \\
\hline Oncocytic variant & $01(100 \%)$ & -- & Females only \\
\hline Tall cell variant & $01(100 \%)$ & -- & Females only \\
\hline Columnar cell variant & $01(100 \%)$ & -- & Females only \\
\hline
\end{tabular}

Classic variant followed by follicular variant is the most common type in females. 37 cases showed metastasis to the regional lymph nodes and is shown in Table-4.

Table-4: Metastasis to the regional lymphnodes.

\begin{tabular}{|l|c|}
\hline Primary variant & No. of cases \\
\hline Classic variant & 33 \\
\hline Follicular variant & 01 \\
\hline Papillary microcarcinoma variant & 01 \\
\hline Warthin like variant & 00 \\
\hline Cribriform morular variant & 01 \\
\hline NIFTP & 00 \\
\hline Oncocytic variant & 01 \\
\hline Tall cell variant & 00 \\
\hline Columnar cell variant & 00 \\
\hline
\end{tabular}




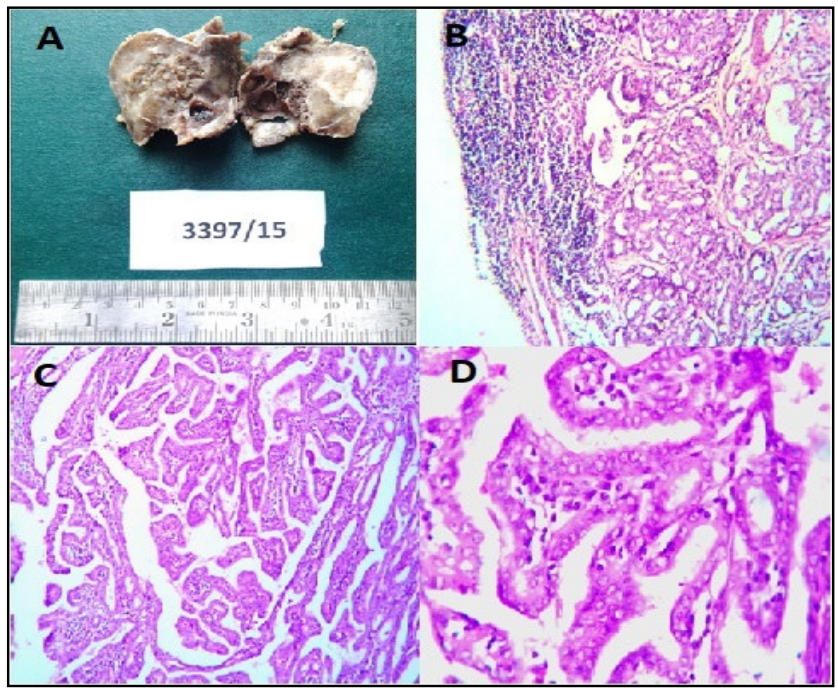

Fig-1: A: Gross picture of PTC showing well-circumscribed lesion and papillary projections, B: Lymphnode metastasis showing characteristic nuclear features papillary carcinoma (H \& E 100X), C \& D: Classic variant showing branching papillary patterns with fibrovascular core, nuclei showing optically clearing (orphan Annie eye nuclei), nuclear grooving, crowding and overlapping. (H\&E 100X) \& (H\&E 400X)

Pathological features: Macroscopically, most of the tumors were both unifocal and multifocal, some well circumscribed. Cut section of the tumors showed solid gray white areas with papillary projections (Figure 1).

\section{Discussion}

PTC is the most common malignant tumor among all thyroid cancers, comprising an estimated $80 \%$ of thyroid cancers [9]. Radiation exposure is one of the well-known risk factors for PTC. Other risk factors include genetic factors, preexisting nodular disease, and association with genetic syndromes such as familial adenomatous polyposis syndrome [9].

Papillary thyroid carcinoma occurs in a relatively younger age group than follicular carcinoma. Youngest patient in the present study was 19 years old. In the present study, a maximum number of patients with PTC were in the third to fourth decade of life. Ranjitha Rao et al [10] observed the maximum incidence of papillary carcinoma in the fourth to fifth decade of life. Ponnuswamy et al [11] observed the highest incidence of papillary carcinoma in the third to fourth decade of life.

In the present study, females predominate over males with a ratio of 3.4:1. Ranjitha Rao et al [10] and Ponnuswamy et al [11] also found female predominance in their studies with female to male ratio of 5:1 and 4.3:1 respectively.

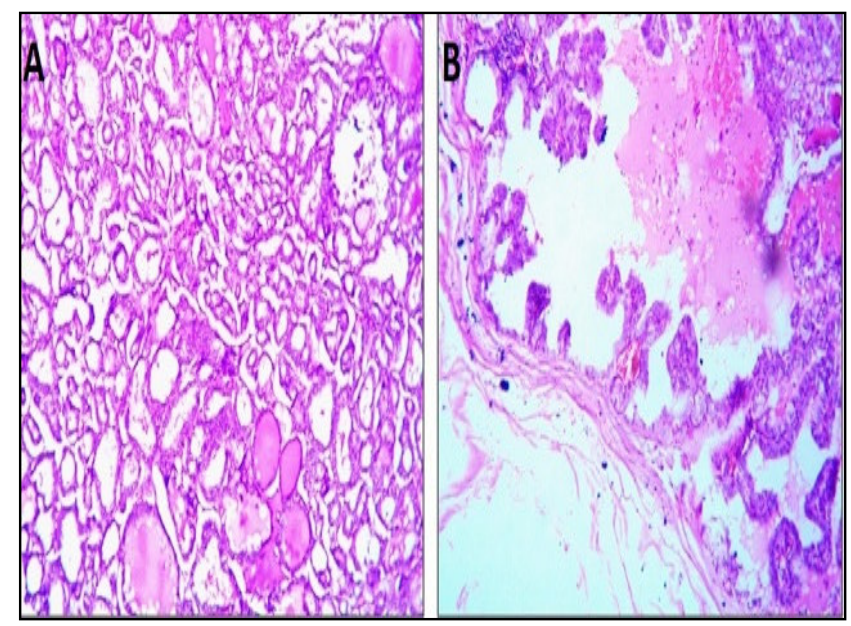

Fig-2: A: Follicular variant of PTC showing follicles of variable sizes. (H\&E 100X), B: NIFTP in which the tumor is surrounded by a fibrous capsule. (H\&E 100X). 


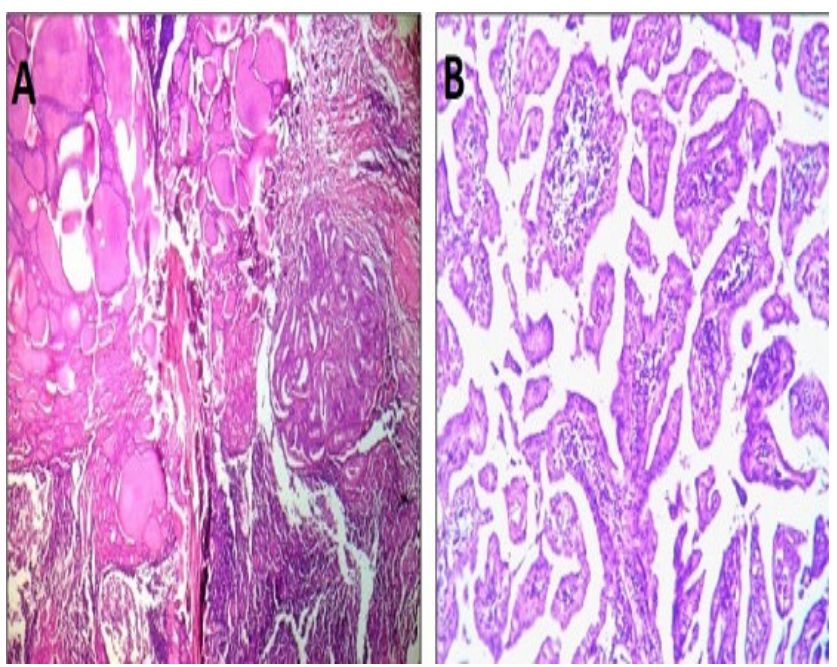

Fig-3: A: Papillary micro carcinoma variant. (H\&E 100X),

B: Warthin like variant showing lymphoplasmacytic infiltrates in the papillae. (H\&E 100X).

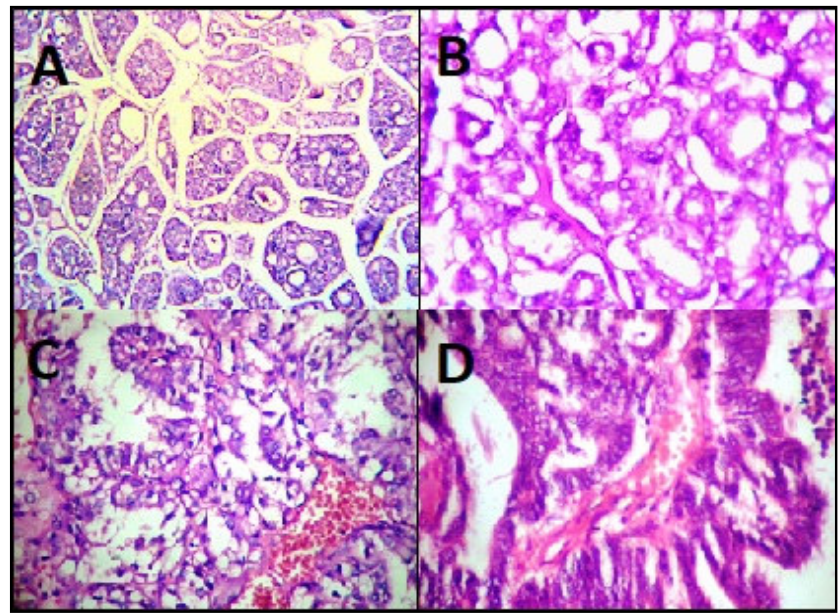

Fig-4: A: Cribriform morular variant showing multifocal morular growth patterns. (H\&E 100X), B: Oncocytic variant showing oncocytic cytoplasm with charactersitic nuclear features. (H\&E 400X), C: Tall cell variant in which the tumor cells are 2-3 times as tall as they are wide with abundant eosinophilic cytoplasm. (H\&E 400X), D: Columnar cell variant showing pseudo stratification. (H\&E 400X)

Papillary carcinoma has different macroscopic morphologies. In the present study, $8 \%$ of the cases had multifocal tumor with the involvement of bilateral lobes. The classic variant is solid or cystic with papillary excrescences (Figure 1A). Tumors are tan colored and firm in consistency. The oncocytic variant showed brown-to-mahogany color. Degenerative changes may be seen focally which may be the result of previous fine-needle aspiration cytology (FNAC) or develop spontaneously. These changes include cystic formation, hemorrhage, and necrosis [10].

Microscopically Papillary carcinomas are diagnosed by their characteristic nuclear features which include optically clear nuclei, also known as "orphan annie" nuclei, nuclear grooves, intranuclear inclusions, and nuclear overcrowding. These features are enough to suggest papillary carcinoma even if the papillary pattern is absent in the tumor [12]. In the present study, all classic variants (Figure 1C \& D) and one case of columnar variant showed arborizing papillary processes with fibrovascular core. Papillary structures may also be seen in nodular goiter, follicular adenoma, or in diffuse hyperplasia because of the infolding of the epithelium. The important distinguishing feature here is the classic nuclear features of PTC which are absent in these benign conditions [9].

Follicular Variant is a papillary carcinoma composed entirely of follicles of variable sizes and is diagnosed with the presence of PTC type nuclei (Figure 2A). It is also referred to as Lindsay tumor [13]. 
NIFTP is entirely surrounded by a capsule or well circumscribed (Figure 2B), with a smooth contour facing the adjacent parenchyma, [14] with follicular growth pattern (with no papillae), but the nuclear alterations of papillary carcinoma.

Papillary microcarcinoma is a variant which was found incidentally measuring $1 \mathrm{~cm}$ in diameter (Figure 3A). Most cases have a stellate configuration and correspond to the lesions formerly known as occult sclerosing carcinoma or no encapsulated sclerosing tumor [15].

Warthin like variant, which is usually circumscribed and rarely encapsulated, shares histological features with Warthin tumour of salivary gland origin. The tumor cells lining the papillae are eosinophilic and large, and the cores of papillae contain a prominent lymphoplasmacytic infiltrates [16.] (Figure 3B).

Cribriform- Morular variant is characterized by the presence of a cribriform pattern of growth and morular formations (Figure 4A). It develops in a sporadic form, [17] or as an extraintestinal component of the familial adenomatous polyposis syndrome, of which it may be the initial clinical manifestation which is seen almost exclusively in females [17-19].

In Oncocytic variant (Figure 4B), the nuclear features remain those of papillary carcinoma, but the cytoplasm is abundant and has a granular oxyphilic quality.

Tall Cell Carcinoma is characterized by papillae lined by a single layer of "tall" cells (the height being two to three times the width) and an abundant acidophilic (oncocytoid) cytoplasm (Figure 4C). The pattern of growth tends to be highly papillary, the papillae are overly elongated, cord-like, and running side-to-side in a regimented, "tram track" fashion. Nuclear pseudo inclusions are particularly prominent [20]. There may be an extensive lymphocytic infiltration of the stroma [21].

Columnar Cell variant showed thin papillae lined by an epithelium with prominent nuclear stratification (Fig 4D); the cytoplasm is clear (sometimes with subnuclear vacuolization, reminiscent of early secretory endometrium), rather than acidophilic as in the tall cell variant; squamoid whorls or morules may be present. [22-27].

In the present study, 37 cases had lymph node metastasis accounting for $37.7 \%$ of the cases (Figure 1B). Ponnuswamy et al [7] observed cervical lymph node metastasis in papillary carcinoma in $72(19.1 \%)$ cases.

Limitations of the study: Information regarding the extra intestinal manifestations of Familial Adenomatous polyposis was not collected for the case that was diagnosed as Cribriform morular variant of papillary thyroid carcinoma, as the patient lost follow up.

\section{Conclusion}

This study highlights the various histological variants of papillary thyroid carcinoma that are encountered. Classic variant of papillary carcinoma thyroid is the most common variant followed by follicular variant. In the present study the most common age group is 31 to 40 years with female predominance in all the variants.

\section{What the study adds to the existing knowledge?}

This study highlights the knowledge of the morphology and incidence of the variants of papillary carcinoma. This is important in the diagnosis of papillary carcinoma variants and its differentiation from other lesions which would help in application of treatment modalities.

\section{Author's contributions}

Dr. Pravallika Uppala: Concepts, Design, Definition of intellectual content, Literature search, Clinical studies,

Experimental studies, Data acquisition, Data analysis, Statistical analysis, Manuscript preparation, Manuscript editing

Dr. I.V. Renuka: Concepts, Design, Definition of intellectual content, Manuscript editing, Manuscript review

Dr. M. Atchyuta: Concepts, Design, Definition of intellectual content, Literature search, Clinical studies, Experimental studies, Data acquisition, Data analysis, Statistical analysis, Manuscript preparation, Manuscript editing

Dr. Naseerudhin Sheik: Concepts, Design, Definition of intellectual content, Data acquisition

Dr. B. Garima: Data acquisition

Dr. K. Sireesha: Data acquisition 
Funding: No funding sources

Conflict of interest: None declared

Ethical Approval: This study was approved by the Institutional Ethics Committee

\section{Reference}

1. Unnikrishnan AG, Menon UV. Thyroid disorders in India: An epidemiological perspective. Indian J Endocrinol Metab. 2011;15(2):S78-81. doi: 10.4103/2230-8210.83329

2. National Centre for Disease Informatics and Research. Trend over time for all sites and on selected sites of cancer and projection of burden of cancer. National Cancer Registry Programme. Indian Council for Medical Research 3 Year Report of Population Based Cancer Registries. Ch. 10. National Centre for Disease Informatics and Research; 2016. p. 89-125.

3. Sonkar AA, Rajamanickam S, Singh D. Papillary thyroid carcinoma: Debate at rest. Indian J Cancer. 2010; 47(2): 206-216. doi: 10.4103/0019-509X.63025.

4. Rosai J. Albares Saavedra J. Asioli S. Fagin J.A. Franssila K. 0. Giordano T. J et al. Papillary thyroid carcinoma. In:Lloyd R. V., Osamura R. Y., Kloppel G., Rosai J. Editors: WHO Classification of Tumours of Endocrine Organs. $4^{\text {th }}$ edition. IARC: Lyon; 2017.p. 81-91.

5. Livolsi VA, Albores-Saavedra J, Asa SL, Baloch ZW, Sobrinho-Simoes M, Wenig B, DeLellis RA, Cady B, Mazafferi EL, Hay I,Fagin JA, Weber AL, Caruso P, Voutilainen PE, Franssila KO, Williams ED, Schneider AB, Nikiforov Y, Rabes HN, Akslen L,Ezzat S, Santoro M, Eng C, Harach HR. Papillary carcinoma.In: DeLellis RA, Lloyd RV, Heitz PU, Eng C editors. WHO classification of tumours, pathology \& genetics: Tumours of endocrine organs. Lyon: IARC Press; 2004. 57-66.

6. Rosai J, Tallini G. Thyroid gland. In: Rosai J editor. Rosai and Ackerman's surgical pathology. $10^{\text {th }}$ ed. New York: Mosby Elsevier 2011:487-564.

7. Nikiforov YE, Ohori NP. Papillary carcinoma. In: Nikiforov YE, Biddinger PW, Thompson LDR editors. Diagnostic pathology and molecular genetics of the thyroid: A comprehensive guide for practicing thyroid pathology. $2^{\text {nd }}$ edition. Philadelphia: Wolter Kluver /Lippincott Williams \&Wilkins; 2012. 183-246.

8. Boerner SL, Asa SL. Biopsy interpretation series: Biopsy interpretation of the thyroid. Epstein JI, editor. Philadelphia: Wolter Kluver /Lippincott Williams \& Wilkins; 2009.
9. Al-Brahim N, Asa SL. Papillary thyroid carcinoma: An overview. Arch Pathol Lab Med 2006; 130(7):1057-1062.

10. Rao R, Giriyan SS, Rangappa PK. Clinicopathological profile of papillary carcinoma of thyroid:A 10-year experience in a tertiary care institute in North Karnataka, India. India. Indian J Cancer. 2017;54(3):514-518. doi: 10. 4103/ijc.IJC_337_17.

11. Karkuzhali P, Yogambal M, Kumar M. An Indian Tertiary Care Hospital Scenario of Papillary Carcinoma of Thyroid. J Clinic Diag Res. 2017;11(6):EC26-EC29. doi: 10. 7860/JCDR/2017/27673.10095.

12. LiVolsi VA. Papillary thyroid carcinoma: An update. Mod Pathol2011;24(2):S1-S9. doi: 10.1038/modpathol. 2010. 129.

13. Lindsay S. Carcinoma of the Thyroid Gland: A Clinical and Pathologic Study of 293 Patients at the University of California Hospital. Spring eld Ill: Charles C Thomas; 1960.

14. Howitt BE, Jia Y, Sholl LM, Barletta JA. Molecular alterations in partially- encapsulated or well-circumscribed follicular variant of papillary thyroid carcinoma. Thyroid. 2013;23(10):1256-1262. doi: 10.1089/thy.2013.0018. Epub 2013 Jul 17.

15. Hazard JB. Small papillary carcinoma of the thyroid. A study with special reference to so-called no encapsulated sclerosing tumor. Lab Invest. 1960;9:86-97.

16. Rosai J. Rosai and Ackerman's surgical pathology ebook. Elsevier Health Sciences; $10^{\text {th }}$ edition. New york: Mosby Elsevier; 2011 Jun 20.p. 487-564.

17. Tomoda C, Miyauchi A, Uruno T, et al. Cribriformmorular variant of papillary thyroid carcinoma: clue to early detection of familial adenomatous polyposis-associated colon cancer. World J Surg. 2004; 28(9):886-889. doi: https:// doi.org/10.1007/s00268-004-7475-4.

18. Xu B, Yoshimoto K, Miyauchi A, Kuma S, Mizusawa $N$, Hirokawa $M$, et al. Cribriform-morular variant of papillary thyroid carcinoma: a pathological and molecular genetic study with evidence of frequent somatic mutations in exon 3 of the beta-catenin gene. $\mathrm{J}$ Pathol. 2003;199(1):58-67. doi: https://doi.org/10.1002/path.1225.

19. Harach HR, Williams GT, Williams ED. Familial adenomatous polyposis associated thyroid carcinoma: a distinct type of follicular cell neoplasm. Histopathol. 1994;25(6):549-561. doi: https://doi.org/10.1111/j.13652559.1994.tb01374.x. 
20. LiVolsi VA. Papillary carcinoma tall cell variant (TCV): a review. Endocr Pathol. 2010;21(1):12-15. doi: 10. 1007/s12022-010-9106-y.

21. Ozaki O, Ito K, Mimura T, Sugino K, Hosoda Y. Papillary carcinoma of the thyroid. Tall-cell variant with extensive lymphocyte in ltration. Am J Surg Pathol. 1996; 20(6):695-698.

22. Evans HL. Columnar-cell carcinoma of the thyroid. A report of two cases of an aggressive variant of thyroid carcinoma. Am J Clin Pathol. 1986;85(1):77-80. doi: https: //doi.org/10.1093/ajcp/85.1.77.

23. Gaertner EM, Davidson M, Wenig BM. The columnar cell variant of thyroid papillary carcinoma. Case report and discussion of an unusually aggressive thyroid papillary carcinoma. Am J Surg Pathol. 1995;19(8):940-947.

24. Sobrinho-Simoes M, Nesland JM, Johannessen JV. Columnar-cell carcinoma. Another variant of poorly differentiated carcinoma of the thyroid. Am J Clin Pathol. 1988;89(2):264-267.doi: https://doi.org/10.1093/ajcp/89.2. 264.

25. Wenig BM, Thompson LD, Adair CF, Shmookler B, Heffess CS. Thyroid papillary carcinoma of columnar cell type: a clinicopathologic study of 16 cases. Cancer. 1998; 82 (4):740-753.

26. Chen JH, Faquin WC, Lloyd RV, Nose V. Columnar cell variant of papillary thyroid carcinoma: a clinicopathologic, molecular and immunophenotypic study of nine cases with a review of the literature. Mod Pathol. 2011; 24(5):739-749.doi: 10.1038/modpathol.2011.2. Epub 2011 Feb 25.

27. Evans HL. Encapsulated columnar-cell neoplasms of the thyroid. A report of four cases suggesting a favorable prognosis. Am J Surg Pathol. 1996;20(10):1205-1211.

\section{How to cite this article?}

Uppala P, I.V. Renuka, M. Atchyuta, Sheik N, B. Garima, K. Sireesha. Spectrum of histologic variants of papillary thyroid carcinoma over a period of 5 years- single institutional study. Trop J Path Micro 2019;5(11):934-941.doi:10.17511/jopm. 2019.i11.16. 